INDONESIAN JOURNAL OF

Clinical Pathology and Medical Laboratory

Majalah Patologi Klinik Indonesia dan Laboratorium Medik

\begin{tabular}{|c|c|c|c|c|c|}
\hline $\begin{array}{c}\text { IJCP \& ML } \\
\begin{array}{c}\text { (Maj. Pat. Klin. } \\
\text { Indonesia \& Lab. Med.) }\end{array}\end{array}$ & Vol. 17 & No. 3 & Hal. 127-177 & $\begin{array}{c}\text { Surabaya } \\
\text { Juli 2011 }\end{array}$ & $\begin{array}{c}\text { ISSN } \\
0854-4263\end{array}$ \\
\hline
\end{tabular}

Diterbitkan oleh Perhimpunan Dokter Spesialis Patologi Klinik Indonesia

Published by Indonesian Association of Clinical Pathologists

Terakreditasi No: 43/DIKTI/Kep/2008, Tanggal 8 Juli 2008 


\section{INDONESIAN JOURNAL OF \\ CLINICAL PATHOLOGY AND MEDICAL LABORATORY \\ Majalah Patologi Klinik Indonesia dan Laboratorium Medik}

\section{DAFTAR ISI}

\section{PENELITIAN}

Creatine Kinase Myocardial Band, Myeloperoxidase, Matrix Metalloproteinase- 9 dan Troponin T Pada IMA

(The Creatine Kinase Myocardial Band, Myeloperoxidase, Matrix Metalloproteinase-9 Activities and Troponin $T$ in Myocardial Infarction)

IA Hutagalung, I Patellongi, R Pakasi, M Arif, AA Mappahya, Hardjoeno

D-Dimer Penderita Sindrom Koroner Akut dan Stenosis

(D-Dimer in Acute Coronary Syndrome and Stenosis)

Birhasani, Lisyani BS, Ria T

Uji Hematologi Pasien Terduga Demam Berdarah Dengue Indikasi Rawat Inap

(Hematology Test of Dengue Hemorrhagic Fever on Suspected Patients Indicated for Hospitalization) Juranah, Darwati Muhadi, Mansyur Arif, Burhanuddin Bahar .

Imunokimiawi PGE2 Usus Ileum yang Kekurangan Energi Protein

(Immunohistochemistry of PGE2 Ileum Intestine Protein Energy Deficiency)

R. Heru Prasetyo

Gamma-glutamyltransferase dan Apolipoprotein B dengan Sindroma Metabolik

(Gamma-glutamyltransferase and Apolipoprotein B with the Metabolic Syndrome)

Tahono, M.I. Diah Pramudianti.

146-150

Umbi Ubi Jalar Ungu Bali (Ipomoea batatas) di Transaminase Serum, Malondialdehide Hepar dan Alkohol Kronis

(Balinese Purple Sweet Potato (Ipomoea batatas L) on SGOT, SGPT, MDA level and Chronic Alcohol) I Wayan Putu Sutirta-Yasa, I Made Jawi, Ida Bagus Ngurah, Anak Agung Ngurah Subawa.

Leukosit Infeksi Bakteri Sistemik

(Leucocyte in Systemic Bacterial Infections)

Meita Hendrianingtyas, MI. Tjahjati DM

Meningitis Tuberculosis

(Meningitis Tuberculosis)

Silvia Rachmayati, Ida Parwati, A Rizal, D Oktavia

Platelet Aggregation In Acute Coronary Syndrome

(Aggregasi Trombosit di Sindroma Koroner Akut)

Sulianty, Adi K Aman..

TELAAH PUSTAKA

Pemetaan Epitop dan Aplikasi Klinisnya

(Epitope Mapping and It's Clinical Aplication)

Jusak Nugraha.

LAPORAN KASUS

Infeksi Virus Rabies di Anak-anak

(Rabies Virus Infection in Children)

A.A.N. Subawa, DGD. Dharma Santhi, A.A Raka Sudewi, IWP. Sutirta Yasa 


\title{
D-DIMER PENDERITA SINDROIM KORONER AKUT DAN STENOSIS
}

\author{
(D-Dimer in Acute Coronary Syndrome and Stenosis)
}

Birhasani, ${ }^{1}$ Lisyani BS, ${ }^{2}$ Ria $\mathbf{T}^{2}$

\begin{abstract}
Acute coronary syndrome (ACS) is the multisystem of coronary artery disease. The clinical manifestation of ACS is acute myocardial infarction (AMI). About 90\% coronary attack is caused by thrombus occlusion in coronary artery. The suspect of thrombosis can be diagnosed definitely by Angiography, but it is invasive. D-dimer used to measure thrombosis abnormality and fibrinolisys. The result of their correlation between D-dimer with ACS is still controversived. The aim of this research is to analyse, the different between plasma $D$-dimer level ACS with stenosis $\geq 50 \%$ and stenosis $<50 \%$. This study used a cross sectional design. The study consist of seventeen specimen ACS with stenosis $\geq 50 \%$ and 17 specimen with stenosis $<50 \%$. Plasma D-dimer level was measured with quantitative agglutination latex method. An independent $t$-test statistical analysis is used in this study. The average Plasma D-dimer of ACS with stenosis $\geq 50 \%$ is $960.2 \pm 404.99 \mu \mathrm{g} / \mathrm{L}$ thus ACS with stenosis $<50 \%$ is $300.3 \pm 128.75 \mu \mathrm{g} / \mathrm{L}(p=0.00)$. The plasma D-dimer level of ACS with stenosis $\geq 50 \%$ is more significant than ACS with stenosis $<50 \%$.
\end{abstract}

Key words: Stenosis, D-dimer, acute coronary syndrome

\begin{abstract}
ABSTRAK
Sindroma koroner akut (SKA) adalah sekumpulan penyakit arteri koroner. Manifestasi klinis antara lain berupa infark miokard akut (IMA). Sekitar 90\% serangan jantung disebabkan oleh penutupan (oklusi) trombus di arteri koroner. Kecurigaan trombosis dapat dipastikan dengan pemotretan pembuluh darah (angiografi), tetapi lebih bersifat sebukan (invasif). D-Dimer dapat dipakai untuk menilai abnormalitas kejadian trombotik dan penguraian fibrin (fibrinolisis). Penelitian D-dimer yang berhubungan dengan SKA hasilnya masih bertentangan pendapat. Penelitian ini ditujukan untuk mengetahui hasil analisis perbedaan kadar D-dimer plasma penderita SKA dengan stenosis $\geq 50 \%$ dan stenosis $<50 \%$. Kajian dilakukan dengan pendekatan cross sectional, masingmasing menggunakan 17 spesimen dari penderita SKA dengan stenosis $\geq 50 \%$ dan stenosis $<50 \%$. Kadar D-dimer plasma diukur secara besaran dengan menggunakan metode penggumpalan getah (latex agglutination) yang diubahsuaikan (modifikasi) dengan menggunakan penganalisis swakerja (automated analyzer). Uji beda menggunakan analisis statistik uji-t bebas (independent t-tes). Rerata kadar D-dimer plasma penderita SKA dengan stenosis $\geq 50 \%$ adalah 960,2 $\pm 404,99 \mu \mathrm{g} / \mathrm{L}$, sedangkan untuk penderita SKA dengan stenosis $<50 \%$ adalah $300,3 \pm 128,75 \mu \mathrm{g} / \mathrm{L}$. Hasil uji statistik didapatkan nilai $p=0,00$. Kadar D-dimer plasma penderita SKA dengan stenosis $\geq 50 \%$ secara statistik lebih tinggi secara bermakna dibandingkan dengan penderita SKA berstenosis $<50 \%$.
\end{abstract}

Kata kunci: Stenosis, D-dimer, sindrom koroner akut

\section{PENDAHULUAN}

Penyakit jantung koroner (PJK) merupakan penyebab utama kematian dan menjadi masalah kesehatan utama di dunia. ${ }^{1}$ PJK didefinisikan sebagai keadaan abnormal tertentu yang disebabkan oleh gangguan fungsi jantung dan pembuluh darah. ${ }^{2,3}$ Faktor kebahayaan terjadinya PJK tersebut antara lain perokok, dislipidemia karena komsumsi lemak jenuh berlebih hingga terjadi pengerasan buluh darah (aterosklerosis) dan tekanan darah tinggi, disglikemia hingga daya tahan glukosa terganggu atau diabetes melitus, kadar asam urat meninggi (hiperurisemia), berkurangnya aktivitas fisik, riwayat keluarga dan kegemukan. ${ }^{4,5}$
Pencetus PJK adalah timbulnya plak kolesterol dan aterosklerosis arteri koroner yang berlangsung lama, sering tanpa gejala terutama di orang lanjut usia, tetapi pada suatu waktu dapat menimbulkan keluhan mendadak, dada nyeri, kelainan EKG dan kelainan petanda jantung karena trombosis arteri koroner dan mengakibatkan sindroma koroner akut (SKA).6,7 Sindrom koroner akut merupakan manifestasi klinis PJK, antara lain dapat berupa infark miokard akut (IMA). ${ }^{5}$ SKA merupakan kasus gawat yang harus segera didiagnosis, disertai pengelolaan yang benar untuk menghindari kecacatan dan kematian..$^{5,6} \mathrm{PJK}$ bermakna didefinisikan sebagai stenosis tertentu yang meliputi lebih dari 50\% penampang (diameter) pembuluh darah. Hasil pemasukan kateter/kateterisasi

\footnotetext{
${ }^{1}$ Laboratorium RSUD Buntok Jl. Patianom No.6 Buntok. Kalimantan-Tengah. E-mail: izza.birhasani@gmail.com

2 Bagian Patologi Klinik Fakultas Kedokteran Universitas Diponegoro Semarang/RSUP Dr. Kariadi Jl. Dr. Sutomo 16-18 Semarang
} 
di penderita aterosklerosis menunjukkan penyempitan lebih dari 50\%. Penyempitan tidak mengganggu aliran darah kecuali kalau telah melebihi $70 \%$ dari rongga (lumen) arteri. Penyumbatan arteri koroner ini dapat sebagian maupun keseluruhan dari satu atau lebih arteri koroner dan atau percabangannya. Derajat stenosis di arteri koroner dapat terlihat dengan kateterisasi dan biasanya diukur dengan pengamatan mata dari persentasi pengurangan diameter relatif terhadap segmen normal yang berdekatan. Trombosis adalah keadaan tertentu pembentukan, pertumbuhan atau terdapatnya trombus tertentu, sedangkan trombus adalah bekuan darah yang terbentuk karena kegiatan penggumpalan (aktivitas koagulasi), yang menyumbat peredaran dan melekat di vena, arteri, kapiler maupun bilik jantung. ${ }^{8,9}$ Fibrin merupakan komponen penting penggumpalan darah, keberadaannya menunjukkan ada aktivitas koagulasi yang terbentuk sebagai hasil pecahan fibrinogen oleh kegiatan trombin. Bekuan fibrin yang terbentuk dalam aktivitas koagulasi kemudian akan dihancurkan oleh plasmin dalam tatanan penguraian fibrin. Hasil akhir proses ini adalah hasilan bentuk sederhana silang hubung (produk degradasi cross-linked) yang disebut D-Dimer. ${ }^{9}$

Kecurigaan dugaan ada trombosis dapat dipastikan dengan pemeriksaan objektif antara lain angiografi yang merupakan pemeriksaan baku, tetapi lebih bersifat invasif. D-Dimer secara tidak langsung dipakai untuk menilai adanya abnormalitas kejadian trombotik, selain itu secara langsung menilai adanya fibrinolisis, dan pemeriksaan relatif yang tidak bersifat invasif serta penafsiran hasilnya lebih mudah tetapi tidak dapat menentukan letak/tempat dan penyebabnya. ${ }^{9}$

Penelitian kadar D-Dimer yang berhubungan dengan PJK sudah banyak dilakukan, tetapi hasil telitian yang membuktikan hubungan kepekatan D-Dimer dengan PJK masih berbeda pendapat. Hasil telitian tertentu dinilai tidak ada hubungan kepekatan D-Dimer plasma dengan berat ringan serta luasnya PJK dengan mempertimbangkan persentase stenosis dan jumlah arteri koroner yang terkena. ${ }^{10}$ Pada beberapa penelitian lain terlihat hubungan kepekatan D-Dimer yang tinggi dengan PJK, dan hasil telitian tersebut mendukung pengertian peranan fibrin di dalam pembuluh (intravaskuler) dalam pembentukan trombosit buluh darah arteri (atherothrombogenesis. ${ }^{11}$

Tujuan penelitian ini adalah membuktikan perbedaan kadar D-Dimer plasma penderita SKA dengan derajat stenosis $\geq 50 \%$ dan derajat stenosis $<50 \%$. Hasil telitian ini diharapkan dapat memberi masukan mengenai kadar D-Dimer plasma penderita SKA dalam upaya penatalaksanaan pasien yang benar untuk menghindari kecacatan dan kematian.

\section{METODE}

Rancangan penelitian ini adalah pengamatan analisis dengan pendekatan cross sectional. Sasaran penelitian adalah penderita dengan sindroma koroner akut yang akan menjalani kateterisasi jantung di unit perawatan jantung RSUP Dr. Kariadi Semarang. Penderita PJK dinyatakan menderita sindroma koroner akut berdasarkan anamnesis dan pemeriksaan fisik, EKG, serta pemeriksaan enzim dan dinyatakan terdapat sumbatan (obstruksi) $\geq$ 50\% dengan angiografi. Penderita PJK dinyatakan menderita sindroma koroner akut apabila berdasarkan anamnesis dan pemeriksaan fisik, EKG, serta pemeriksaan enzim dan dinyatakan terdapat sumbatan < 50\% dengan angiografi. Penelitian ini dikerjakan pada bulan Nopember 2009 sampai Januari 2010 dan telah disetujui oleh komisi etik penelitian kesehatan Fakultas Kedokteran Universitas Diponegoro Semarang. Seluruh subjek penelitian diminta menandatangani surat persetujuan tindakan secara tertulis, kemudian diwawancarai, pengisian borang senarai pertanyaan (kuesioner) dan pemeriksaan fisik. Sampel terdiri dari 34 subjek, dibagi dalam 2 kelompok masing-masing 17 subjek penderita SKA dengan derajat stenosis $\geq 50 \%$ dan 17 subjek penderita SKA dengan derajat stenosis $<50 \%$.

Pemilihan subjek dilakukan secara pengambilan contoh berturutan (consecutive sampling) dengan patokan kesertaan sebagai berikut: laki-laki maupun perempuan, usia $\geq 40$ tahun, berat badan/IMT 18,525,0, suhu tubuh normal (suhu aksiler: $36,5-37,2^{\circ} \mathrm{C}$ ), jumlah trombosit darah tepi 150.000-450.000 sel/UL, khusus untuk subjek penelitian perempuan: daur haid teratur, tekanan < 140/90 mmHg.

Penderita SKA yang diprogram untuk kateterisasi jantung diambil sampel darah venanya, kemudian dimasukan kedalam wadah hampa udara (vacutainer) yang mengandung sodium citras 9:1 dan dikirim ke laboratorium tanpa perlakuan khusus. Kemudian sampel ini dipusingkan (sentrifugasi) untuk mendapatkan supernatan, atau supernatan yang dapat disimpan pada suhu $-20^{\circ} \mathrm{C}$ stabil sampai 1 bulan. Metode yang dipakai untuk mengukur kadar D-Dimer secara kuantitatif adalah latex agglutination yang dimodifikasi dengan menggunakan automated analyzer. Alat yang digunakan adalah Coagulometer Sysmex CA 1500. Kadar D-dimer dinyatakan dalam $\mu \mathrm{g} / \mathrm{L}$. Titik potong (cut off point) $500 \mu \mathrm{g} / \mathrm{L}$. Hasil $<500 \mu \mathrm{g} / \mathrm{L}$ dinyatakan negatif dan $\geq 500 \mu \mathrm{g} / \mathrm{L}$ dinyatakan positif. Analisis statistik yang digunakan ialah uji -t. 


\section{HASIL DAN PEMBAHASAN}

Berdasarkan data dari 34 subjek yang telah dikumpulkan, terdapat 17 subjek telitian dengan derajat stenosis $\geq 50 \%$ dan 17 subjek telitian dengan derajat stenosis $<50 \%$

Tabel 1. Distribusi frekuensi jenis kelamin berdasarkan derajat stenosis

\begin{tabular}{lccc}
\hline $\begin{array}{c}\text { Jenis } \\
\text { kelamin }\end{array}$ & Stenosis $<\mathbf{5 0 \%}$ & Stenosis $\geq \mathbf{5 0 \%}$ & n \\
\hline Laki-laki & $7(41,2 \%)$ & $9(52,9 \%)$ & 16 \\
Perempuan & $10(58,8 \%)$ & $8(47,1 \%)$ & 18 \\
\hline Jumlah & $17(100 \%)$ & $17(100 \%)$ & 34 \\
\hline
\end{tabular}

Tabel 1 menunjukkan derajat stenosis $\geq 50 \%$ sebagian besar terdapat di laki-laki yaitu 9 orang $(52,9 \%)$, sebaliknya dengan derajat stenosis $<50 \%$ sebagian besar perempuan yaitu sebanyak 10 orang $(58,8 \%)$.

Tabel 2. Distribusi subjek telitian berdasarkan kelompok umur

\begin{tabular}{lllrr}
\hline $\begin{array}{c}\text { Kelompok } \\
\text { umur }\end{array}$ & $\begin{array}{c}\text { Stenosis } \\
\mathbf{2 5 0 \%}\end{array}$ & $\begin{array}{c}\text { Stenosis } \\
<\mathbf{5 0 \%}\end{array}$ & n & \multicolumn{1}{c}{$\%$} \\
\hline 31-40 tahun & 0 & $2(5,9 \%)$ & 2 & 5,9 \\
$41-50$ tahun & $5(14,7 \%)$ & $3(8,8 \%)$ & 8 & 23,5 \\
$51-60$ tahun & $7(20,6 \%)$ & $7(20,6 \%)$ & 14 & 41,2 \\
61-70 tahun & $4(11,8 \%)$ & $3(8,8 \%)$ & 7 & 20,6 \\
$71-80$ tahun & $1(2,9 \%)$ & $2(5,9 \%)$ & 3 & 8,8 \\
\hline Jumlah & $17(50 \%)$ & $17(50 \%)$ & 34 & 100,0 \\
\hline
\end{tabular}

Umur subjek termuda adalah 40 tahun dan tertua adalah 75 tahun. Berdasarkan golongan umur, tampak bahwa sebagian besar subjek telitian berusia antara 51 sampai dengan 60 tahun $(41,2 \%)$. Rerata umur subjek telitian adalah 55,9 tahun dengan simpang baku 10,59 tahun dan median 58,0 tahun.

Setelah dilakukan uji kenormalan untuk data kadar plasma D-Dimer di semua subjek, menunjukkan hasil data berdistribusi normal dengan uji SaphiroWilk. Kemudian diuji statistik parametrik yaitu uji-t bebas, dan didapat hasil yang bermakna $(p=0,00)$.

Tabel 3. Kadar D-Dimer menurut kelompok subjek

\begin{tabular}{rcc}
\hline Kelompok subjek & Rerata \pm SB $\mu \mathbf{g} / \mathbf{L}$ & p $^{*}$ \\
\hline Derajat stenosis $<50 \%$ & $300,2 \pm 128,75$ & \\
Derajat stenosis $\geq 50 \%$ & $960,2 \pm 404,99$ & 0,00 \\
\hline
\end{tabular}

* independent $t$-tes

Tabel 3 menunjukkan bahwa rerata kadar D-Dimer plasma di kelompok subjek dengan derajat stenosis $\geq 50 \%$ jauh lebih tinggi dibandingkan dengan kelompok subjek dengan derajat stenosis $<50 \%(\mathrm{p}=$ $0,00)$.

Grafik kadar D-Dimer plasma tersebut menunjukkan nilai median kelompok subjek SKA

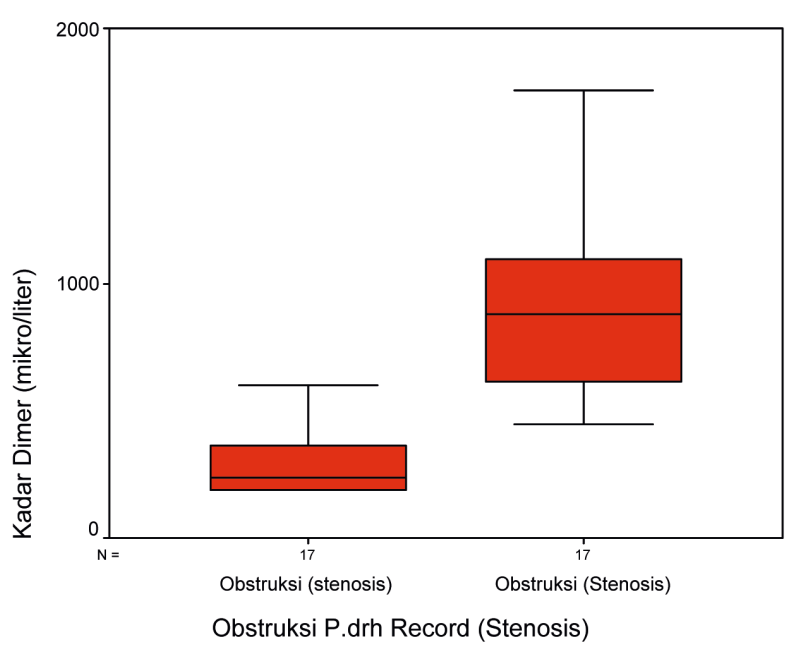

Gambar 1. Grafik kadar D-Dimer Plasma menurut kelompok subjek.

dengan derajat stenosis $\geq 50 \%$ jauh lebih tinggi dibandingkan dengan nilai median kelompok subjek SKA dengan derajat stenosis $<50 \%$. Kelompok subjek SKA dengan derajat stenosis $<50 \%$ tampak data lebih beragam daripada kelompok subjek SKA $\geq 50 \%$. Kedua kelompok menunjukkan gambaran distribusi yang tidak normal dengan nilai median yang mendekati batas bawah (batas yang ditunjukkan dalan kotak/box).

Pada penelitian ini tampak bahwa sebagian besar subjek berusia antara 51-60 tahun $(41,2 \%)$ dengan rerata usia 55,9 $\pm 10,59$ tahun. Hasil Riskesdas tahun 2007 menunjukkan PJK menempati peringkat ke-3 penyebab kematian pada usia di atas 45 tahun setelah strok dan tekanan darah tinggi. ${ }^{12} \mathrm{Di}$ sindroma koroner akut, stenosis dapat terjadi pada beberapa pembuluh darah koroner dengan derajat stenosis yang berbedabeda. Pada penelitian ini derajat stenosis ditentukan berdasarkan hasil angiografi di salah satu pembuluh darah yang mengalami stenosis, yaitu yang derajat stenosisnya terbesar diambil.

Pada penelitian ini didapat perbedaan yang bermakna rerata kadar D-Dimer plasma antara kelompok subjek SKA dan derajat stenosis $\geq 50 \%$ serta stenosis derajat $<50 \%$, yaitu rerata kadar D-Dimer plasma kelompok subjek SKA berderajat stenosis $\geq 50 \%$ lebih tinggi dibandingkan dengan yang berderajat stenosis $<50 \%$. Hasil telitian ini sesuai dengan kajian sebelumnya. Koenig dkk menemukan kadar D-dimer plasma bernasab kuat dengan keberadaan CAD bebas di pasien dengan angina pektoris stabil. Hasil ini mendukung pemikiran peran serta fibrin di dalam pembuluh darah ke arah pembentukan trombosit buluh darah arteri (atherothrombogenesis). ${ }^{12}$ Bayes-Genis, dkk. melaporkan bahwa kadar D-Dimer plasma dan fibrinogen bernasab kuat di pasien infark miokard dan angina tidak stabil. ${ }^{13}$ 
D-Dimer dikenal sebagai hasil bentuk sederhana hubungan silang (produk degradasi cross linked) yang merupakan hasil akhir pemecahan bekuan fibrin oleh plasmin dalam sistem fibrinolitik. Plak yang robek akan diselubungi oleh trombus dan merupakan penyebab utama kejadian sindroma kurang darah jaringan otot jantung (iskemik miokardium). Bila trombus besar dan menghambat aliran darah koroner, terjadilah serangan jantung. Trombus bersifat menggumpal dan mengurai dengan akibat sumbatan koroner yang bersifat tidak menetap (intermiten). Penguraian trombus ini tidak lepas dari pengaruh plasmin, yang merupakan hasil akhir bentuk sederhana fibrin yang stabil dan khas yaitu D-Dimer. Kepekatan D-Dimer plasma dapat mewakili petunjuk penguraian fibrin (indikasi fibrinolisis), karena uji ini akan memberi arti untuk mengukur aktivitas fibrinolitik dalam darah. ${ }^{14}$ hasil uji tertentu yang menunjukan kadar D-Dimer plasma di atas nilai rujukan dapat menandai bahwa ada trombus. ${ }^{11}$

Sindroma koroner akut sesungguhnya merupakan respons imunologik akut tertentu yang berlebihan, sehingga dapat terbentuk trombus yang besar dan menutup rongga (lumen) pembuluh darah koroner yang sudah mengalami aterosklerosis. Aterotrombosis yang terjadi dapat menyebabkan penutupan sebagian (oklusi parsial) atau keseluruhan pembuluh darah koroner. Karena itu sebab gejala klinis sindroma koroner akut sangat beragam dari yang ringan sampai infark miokard akut yang berat. Yaitu karena terbentuk trombus kecil (mikro trombus) sampai trombus besar (makro trombus) besar. Kerusakan endotelium merupakan kecenderungan (predisposisi) untuk terjadi pelekatan (adhesi) trombosit yang berlangsung dengan cepat. Adhesi trombosit ini sangat bergantung dengan protein plasma yang disebut faktor von Willebrand's (vWF) yang dibuat/ bentuk oleh endotel dan megakariosit. Di samping itu trombosit juga akan melekat di trombosit lain (trombosit gumpalan/agregasi), untuk itu diperlukan ADP, ion kalsium dan fibrinogen. Selama membuat gumpalan terjadi perubahan bentuk trombosit dari bentuk cakram menjadi bulat, yang berakibat butiran (granula) trombosit akan terkumpul di tengah dan melepaskan isinya.

Ada atau tidak keberadaan trombosis bergantung eseimbangan antara pendahulu pergumpalan (prokoagulan) dan sistem fibrinolitik. Penguraian fibrin adalah proses kegiatan ensima (aktivitas enzym) hidrolitik terjadi. Komponen sistem fibrinolitik adalah plasminogen, penggiat/pengaktif plasminogen, plasmin, fibrin, FDP dan inhibitor aktivator plasminogen. ${ }^{15}$ Plasmin mencerna fibrin dari fibrinogen secara progresif mengurangi bekuan. Penguraian fibrin dikendalikan oleh sistem aktivator plasminogen (tPA) dengan menggiatkan plasminogen menjadi plasmin dan menghasilkannya dalam bentuk fibrin sederhana (degradasi). Sistem fibrinolisis mencakup beberapa penghambat. Seperti $\alpha$-2 antiplasmin adalah penghambat cepat aktivitas plasmin dan $\alpha-2$ makroglobulin merupakan penghambat tepat guna yang lambat terhadap aktivitas plasmin. Sistem ini dikendalikan oleh penghambatnya yaitu tPA, PAI-1 dan $\alpha$-a antiolasmin.

Pengurangan kegiatan urai fibrin (reduksi aktivitas fibrinolitik) dapat meningkatkan kebahayaan kejadian trombosis kardiovaskular. Penggiat (aktivator) farmakologik saat ini yang digunakan untuk pengobatan trombolisis meliputi streptokinase, urokinase dan tPA. Urokinase secara langsung bekerja menggiatkan plasminogen menjadi plasmin dan streptokinase membentuk gabungan streptokinase plasminogen yang kemudian mengubah plasminogen menjadi plasmin. ${ }^{16}$

\section{SIMPULAN DAN SARAN}

Rerata kadar D-Dimer plasma pasien/penderita SKA dengan derajat stenosis $\geq 50 \%$ lebih tinggi dibandingkan dengan derajat stenosis $<50 \%$. Keperluan pemeriksaan kadar D-Dimer plasma pasien SKA untuk meramalkan keluasan stenosis di arteri koronaria, sehingga dapat dipertimbangkan tindakan lebih lanjut guna menurunkan angka kematian SKA.

\section{DAFTAR PUSTAKA}

1. Baraas F. Respons imunologi. Dalam: Kardiologi molekuler: Bagian Kardiologi FKUI/RS Jantung Harapan Kita, Jakarta, 2006; 194-246.

2. Lisyani BS. C- Reactive Protein, petanda inflamasi untuk menilai risiko penyakit. Dalam: MI Tjahjati, Banundari RH, Lily V, Ima AL. Seminar petanda penyakit kardiovaskuler sebagai POCT. Semarang: Himpunan Kimia Klinik Indonesia, 2006; 16-29.

3. Palupessi JMCH. Penyakit jantung koroner. Dalam: Publikasi kardiologi anak. Jakarta, IDAI. 1994; 404-15.

4. Hardjoeno. Fasting and two hours blood glucose levels in old age. Procedings of the $9^{\text {th }}$ World association of pathology and laboratory medicine (WasPalm) Congress: 2003; May 15-18, Busan, 2003.

5. Lawrence .Coronary heart disease. In: Barry M, Massie, Thomas M, editors. Current medical diagnosis and treatment. $43^{\text {th }}$ ed, New York, McGraw-Hill, 2004; 326-9.

6. Hardjoeno. Metabolic syndrome and cardiovascular disease. Proceedings of the 10th Asian society of clinical pathology and laboratory medicine, AsPalm Congress: 2004 Oct 22-25, Medan, 2004.

7. Hardjoeno. Obesitas, sindroma metabolik dan Diabetes Mellitus Tipe 2, seminar PDS Patklin, Banjarmasin, 2005.

8. Purwanto AP. Trombosis, patofisiologi dan diagnosis laboratorik. Dalam: Simposium penyakit jantung koroner aspek laboratorik. Semarang, 18 Juni 2005.

9. Lisyani BS. D-dimer sebagai parameter tambahan untuk trombosis, fibrinolisis dan penyakit jantung. Dalam: MI Tjahjati, Banundari RH, Lily V, Ima AL. Seminar petanda penyakit kardiovascular sebagai point care test, Semarang 6 Mei 2006.

10. Tataru MC, Heinrich J, Junker R, Schulte H, Von Eckardstein A, Assmann G, et al. D-dimer in relation to the severity of arteriosclerosis in patients with stable angina pectoris after myocardial infarction. Eur Heart J 1999; 20: 1493-1502. 
11. Koenig W, Rothenbacher D, Hoffmeister A, Griesshammer M, Brenner H. Plasma fibrin D-dimer levels and risk of stable coronary artery disease: results of a large case-control study. Arterioscler Thromb Vasc Biol. 2001; 21: 1701-5.

12. Dinas Kesehatan Kabupaten Banggai. Hipertensi faktor resiko utama penyakit kardiovaskuler. [Cited 2009 Sept 18]. Avalaible from: http://dinkesbanggai.wordpress.com/2009/03/10/ hipertensi-faktor-resiko-utama-penyakit-kardiovaskuler/).

13. Bayes-Genis A, Mateo J, Santalo M, Oliver A, Guindo J, Badimon L, et al. D-Dimer is an early diagnostic marker of coronary ischemia in patients with chest pain. Am Heart J. 2000;140: 379-84.
14. Purwanto AP. Adiponektin sebagai marker penyakit jantung dan pembuluh darah. Dalam: Kumpulan naskah lengkap kongres nasional VI \& pertemuan ilmiah tahunan perhimpunan Dokter Spesialis Patologi Klinik, Makassar, 1-4 November 2007.

15. Rahajuningsih DS. Fisiologi hemostasis dan fibrinolisis. Dalam: Farida O. Hemostasis dan Trombosis. Departemen Patologi klinik FKUI/RSCM, 2007; 1-45.

16. Hoffman. Hematology: Basic principles and practice. $3^{\text {th }}$ ed, Amerika, Churcill Livingstone Inc, 2000; 1000-33. 